Supporting Information

\title{
Gas Permeable Inorganic Shell Improves the Coking Stability and Electrochemical Reactivity of Pt towards Methane Oxidation
}

\author{
Jongsu Seo ${ }^{\dagger}$, Nikolai Tsvetkov \\ Jeong Hwan Kim*§, ", Jeung Ku Kang*†,* and WooChul Jung* ${ }^{* \dagger}$
}

\author{
AUTHOR INFORMATION \\ Corresponding Author \\ *(Jeong Hwan Kim) Email: jkim@hanbat.ac.kr \\ *(Jeung Ku Kang) Email: jeung@kaist.ac.kr \\ *(WooChul Jung) Email: wcjung@kaist.ac.kr
}




\section{Table of Contents}

Section S1. Summary of examples of ALD related paper

Section S2. Method details

Section S3. Element analysis

Section S4. ALD growth behavior

Section S5. Electronic structure characterization

Section S6. Influence of $\mathrm{Al}_{2} \mathrm{O}_{3}$ coating on EIS performance

Section S7. XRD results of a target and a thin film

Section S8. Influence of $\mathrm{Al}_{2} \mathrm{O}_{3}$ coating on surface oxygen exchange kinetic and estimation of surface coverage

Section S9. Stability of Pt nanoparticles

Section S10. References 
Section S1. Summary of examples of ALD related paper

\begin{tabular}{|c|c|c|c|c|c|}
\hline Journal & Year & First author & Overcoat & Metal particle & Application \\
\hline Appl. Catal., B. ${ }^{1}$ & 2019 & McNeary, W.W & $\mathrm{WN}$ & $\mathrm{Pt}$ & ORR(PEMFC) \\
\hline J. Vac. Sci. Technol. $\mathbf{A}^{2}$ & 2019 & Jackson, D. H & $\mathrm{CeO}_{2}, \mathrm{ZrO}_{2}$ & $\mathrm{Cu}$ & $\mathrm{NO}_{\mathrm{x}}$ removal reaction \\
\hline ACS. Appl. Nano. Mater. ${ }^{3}$ & 2018 & Sudheeshkumar, V & $\mathrm{Al}_{2} \mathrm{O}_{3}$ & $\mathrm{Au}$ & 4-nitrophenol reduction \\
\hline J. Am. Chem. Soc. ${ }^{4}$ & 2018 & $\mathrm{Wu}, \mathrm{L}$ & $\mathrm{TiO}_{2}$ & $\mathrm{Ru}$ & $\begin{array}{c}\text { Water photoelectron- } \\
\text { oxidation }\end{array}$ \\
\hline ACS. Appl. Nano. Mater. ${ }^{5}$ & 2018 & Cai, J & $\mathrm{NiO}$ & $\mathrm{Pt}$ & CO oxidation \\
\hline ACS Catal. ${ }^{6}$ & 2017 & Yang, N. & $\mathrm{MnO}$ & $\mathrm{Rh}$ & Syngas conversion \\
\hline ACS Catal. ${ }^{7}$ & 2017 & Liang, $\mathrm{H}$ & $\mathrm{TiO}_{2}$ & $\mathrm{Pt}$ & Hydrogenation \\
\hline Appl. Catal. ${ }^{8}$ & 2017 & $\mathrm{Hu}, \mathrm{Q}$. & $\mathrm{Fe}_{2} \mathrm{O}_{3}$ & $\mathrm{Pt}$ & Hydrogenation \\
\hline Chin. J. Catal. $^{9}$ & 2017 & Yi, H. & $\mathrm{Fe}_{2} \mathrm{O}_{3}$ & $\mathrm{Pd}$ & Hydrogenation \\
\hline Angew. Chem., Int. Ed. ${ }^{10}$ & 2017 & Zhang, J & $\mathrm{TiO}_{2}$ & $\mathrm{Pt}$ & Hydrogenation \\
\hline ACS Catal. ${ }^{11}$ & 2016 & Lei, Y. & $\mathrm{ZnO}$ & $\mathrm{Pt}$ & Propanol reforming \\
\hline J. Phys. Chem. $C^{12}$ & 2016 & Wang, C. & $\mathrm{TiO}_{2}$ & $\mathrm{Au}$ & CO oxidation \\
\hline Angew. Chem., Int. Ed. ${ }^{13}$ & 2016 & $\mathrm{Ge}, \mathrm{H}$ & $\mathrm{TiO}_{2}$ & $\mathrm{Pt}$ & Hydrogenation \\
\hline ACS Catal. ${ }^{14}$ & 2015 & Yi, H & $\mathrm{Al}_{2} \mathrm{O}_{3}$ & $\mathrm{Pd}$ & Hydrogenation \\
\hline ACS Catal. ${ }^{15}$ & 2015 & Kim, H. J. & $\mathrm{TiO}_{2}$ & Co & Water electro-oxidation \\
\hline ACS Catal. ${ }^{16}$ & 2015 & Onn, TM & $\mathrm{ZrO}_{2}$ & Pd & Methane oxidation \\
\hline J. Catal. ${ }^{17}$ & 2015 & Zhang, H & $\mathrm{Al}_{2} \mathrm{O}_{3}, \mathrm{TiO}_{2}$ & $\mathrm{Cu}$ & Hydrogenation \\
\hline J. Catal. ${ }^{18}$ & 2015 & Lee, $\mathrm{J}$ & $\mathrm{TiO}_{2}$ & Co & Hydrogenation \\
\hline ACS Catal. ${ }^{19}$ & 2014 & Alba-Rubio, A. C. & $\mathrm{Al}_{2} \mathrm{O}_{3}$ & $\mathrm{Cu}$ & Hydrogenation \\
\hline Angew. Chem., Int. Ed. ${ }^{20}$ & 2014 & Zhang, H & $\mathrm{Al}_{2} \mathrm{O}_{3}$ & $\mathrm{Pd}$ & Hydrogenation \\
\hline ChemCatChem $^{21}$ & 2014 & O'Neill & $\mathrm{Al}_{2} \mathrm{O}_{3}$ & $\mathrm{Cu}$ & Hydrogenation \\
\hline Energy Environ. Sci ${ }^{22}$ & 2014 & Lee, J & $\mathrm{Al}_{2} \mathrm{O}_{3}, \mathrm{TiO}_{2}$ & $\mathrm{Co}$ & Hydrogenation \\
\hline J. Catal ${ }^{23}$ & 2014 & Zhang, H & $\mathrm{Al}_{2} \mathrm{O}_{3}$ & $\mathrm{CuCrO}_{4}$ & Hydrogenation \\
\hline Angew.Chem., Int. Ed. ${ }^{24}$ & 2013 & O'Neill & $\mathrm{Al}_{2} \mathrm{O}_{3}$ & $\mathrm{Cu}$ & Hydrogenation \\
\hline Appl. Catal. ${ }^{25}$ & 2013 & Seo, H. O & $\mathrm{TiO}_{2}$ & $\mathrm{Ni}$ & Methane reforming \\
\hline ACS Catal. ${ }^{26}$ & 2012 & Lobo, $\mathrm{R}$ & $\mathrm{CeO}_{2}, \mathrm{TiO}_{2}$ & $\mathrm{Pt}$ & Propanol reforming \\
\hline Chem. Mater ${ }^{27}$ & 2012 & $\mathrm{Lu}, \mathrm{J}$ & $\mathrm{Al}_{2} \mathrm{O}_{3}$ & $\mathrm{Pd}$ & Film growth mechanism \\
\hline Science $^{28}$ & 2012 & $\mathrm{Lu}, \mathrm{J}$ & $\mathrm{Al}_{2} \mathrm{O}_{3}$ & $\mathrm{Pd}$ & Oxidative dehydration \\
\hline Catal. Lett ${ }^{29}$ & 2011 & Feng, $\mathrm{H}$ & $\mathrm{Al}_{2} \mathrm{O}_{3}$ & $\mathrm{Pd}$ & Methanol decomposition \\
\hline Catal. Lett ${ }^{30}$ & 2011 & Kim, D. W & $\mathrm{TiO}_{2}$ & $\mathrm{Ni}$ & Methane reforming \\
\hline J. Phys. Chem. C ${ }^{31}$ & 2008 & Ma, Z & $\mathrm{TiO}_{2}, \mathrm{SiO}_{2}, \mathrm{Al}_{2} \mathrm{O}_{3}$ & $\mathrm{Au}$ & $\mathrm{CO}$ and $\mathrm{H}_{2}$ oxidation \\
\hline
\end{tabular}

Table S1 List of previous studies that stabilized metal nanocatalysts via oxide atomic layer deposition. aplication of this concept to high-temperature electrochemical devices such as solid oxide fuel cell electrodes has never been reported. 


\begin{tabular}{|c|c|c|c|c|}
\hline Journal & Year & First author & Overcoat & Purpose \\
\hline ACS Omega $^{32}$ & 2017 & Karimaghaloo, A. & YSZ & \multirow{9}{*}{ To prevent decomposition of electrodes } \\
\hline Sci. China. Technol. Sc. ${ }^{33}$ & 2017 & Zhou, K & YSZ & \\
\hline Int. J. Precis. Eng. Man ${ }^{34}$ & 2016 & Chang, I. & $\mathrm{SnO}_{2}$ & \\
\hline Nanotechnology 35 & 2016 & Neoh, K. C. & $\mathrm{CeO}_{2}$ & \\
\hline Adv. Energy Mater. ${ }^{36}$ & 2015 & Chang, I. & YSZ & \\
\hline Electrochem. Commun. ${ }^{37}$ & 2015 & Liu, K. Y. K. Y. & $\mathrm{ZrO}_{2}$ & \\
\hline J. Power Sources ${ }^{38}$ & 2015 & Li, Y. K. & YSZ & \\
\hline Chem. Mater. ${ }^{39}$ & 2013 & Gong, $\mathrm{Y}$. & $\mathrm{ZrO}_{2}$ & \\
\hline Nano Lett. ${ }^{40}$ & 2013 & Gong, Y. & $\mathrm{ZrO}_{2}$ & \\
\hline ACS Appl. Mater. Interfaces ${ }^{41}$ & 2016 & Jeong, H. J. & $\mathrm{Ni}, \mathrm{Ru}$ & \multirow{14}{*}{ To modulate electrode surfaces } \\
\hline ACS Catal. ${ }^{42}$ & 2015 & Jeong, H. J. & $\mathrm{Pt}, \mathrm{Ru}$ & \\
\hline Dalton Trans. ${ }^{43}$ & 2015 & Ahvenniemi, E. & $\mathrm{La}_{1-\mathrm{x}} \mathrm{Sr}_{\mathrm{x}} \mathrm{CoO}_{3}$ & \\
\hline J. Power Sources ${ }^{44}$ & 2015 & Jeong, H. J. & $\mathrm{Ru}$ & \\
\hline J. Electrochem. Soc. ${ }^{45}$ & 2015 & Choi, H. J. & $\mathrm{CoO}_{\mathrm{x}}$ & \\
\hline Int. J. Hydrog. Energy ${ }^{46}$ & 2014 & $\mathrm{Ji}, \mathrm{S}$. & $\mathrm{Pt}$ & \\
\hline J. Electrochem. Soc. ${ }^{47}$ & 2013 & Anthony, S. Y. & $\mathrm{Al}_{2} \mathrm{O}_{3}, \mathrm{SrO}, \mathrm{CeO}_{2}$ & \\
\hline Phys. Chem. Chem. Phys. ${ }^{48}$ & 2013 & An, J. & $\mathrm{Pt}$ & \\
\hline Adv. Energy Mater. ${ }^{49}$ & 2012 & Chao, C. C. & $\mathrm{Pt}$ & \\
\hline J. Electrochem. Soc. ${ }^{50}$ & 2010 & Shim, J. H. & $\mathrm{Pt}$ & \\
\hline Dalton Trans. ${ }^{51}$ & 2009 & Lie, $M$. & $\mathrm{La}_{1-\mathrm{x}} \mathrm{Sr}_{\mathrm{x}} \mathrm{FeO}_{3}$ & \\
\hline Chem. Mater. ${ }^{52}$ & 2008 & Jiang, $\mathrm{X}$. & $\mathrm{Pt}$ & \\
\hline Solid State Ion. ${ }^{53}$ & 2008 & Holme, T.P. & $\mathrm{La}_{\mathrm{x}} \mathrm{Sr}_{1-\mathrm{x}} \mathrm{MnO}_{3}$ & \\
\hline J. Mater. Chem. ${ }^{54}$ & 2007 & Nilsen, $\mathrm{O}$. & $\mathrm{La}_{1-\mathrm{x}} \mathrm{Ca}_{\mathrm{x}} \mathrm{MnO}_{3}$ & \\
\hline Sci. Rep. ${ }^{55}$ & 2016 & $\mathrm{Li}, \mathrm{Y}$. & GDC & \multirow{14}{*}{ To fabricate dense electrolytes } \\
\hline ACS Appl. Mater. Interfaces ${ }^{56}$ & 2015 & Ji, S. & YSZ & \\
\hline Nano Lett. ${ }^{57}$ & 2013 & An, J. & YDC & \\
\hline J. Mater. Chem. ${ }^{58}$ & 2011 & Fan, Z. & YDC & \\
\hline Chem. Mater. ${ }^{59}$ & 2009 & Ballee, E. & YDC & \\
\hline Chem. Mater. ${ }^{60}$ & 2009 & Shim, J. H. & $\mathrm{BaZrO}_{3}$ & \\
\hline J. Mater. Chem. ${ }^{61}$ & 2009 & Brahim, C. & $\mathrm{ZrO}_{2}, \mathrm{In}_{2} \mathrm{O}_{3}$ & \\
\hline Nano Lett. ${ }^{62}$ & 2009 & Chao, C. C. & YSZ & \\
\hline Nano Lett. ${ }^{63}$ & 2008 & Su, P. C. & YSZ & \\
\hline Appl. Surf. Sci. ${ }^{64}$ & 2007 & Brahim, C. & YSZ & \\
\hline Chem. Mater. ${ }^{65}$ & 2007 & Shim, J. H. & YSZ & \\
\hline Electrochem. Solid-State Lett. ${ }^{66}$ & 2007 & Ginestra, C. N. & YSZ & \\
\hline Ionics $^{67}$ & 2003 & Gourba, E. & GDC & \\
\hline Phys. Chem. Solids ${ }^{68}$ & 2003 & Bernay, C. & YSZ & \\
\hline
\end{tabular}

Table S2 List of previous studies that introduced atomic layer deposition in solid oxide fuel cells. No studies have been reported to stabilize metal nanocatalysts in this field. 


\section{Section S2. Method details}

Powder preparation. LSCM powders were prepared by glycine-nitrate method. An aqueous solution containing $\mathrm{La}\left(\mathrm{NO}_{3}\right)_{3} \cdot 6 \mathrm{H}_{2} \mathrm{O}$ (Alfa Aesar, $99.99 \%$ ), $\mathrm{Sr}\left(\mathrm{NO}_{3}\right)_{2}$ (Alfa Aesar, $99.97 \%$ ) $\mathrm{Cr}\left(\mathrm{NO}_{3}\right)_{3} \cdot 9 \mathrm{H}_{2} \mathrm{O}$ (Sigma-aldrich, $99 \%$ ), $\mathrm{Mn}\left(\mathrm{NO}_{3}\right)_{2} \cdot 6 \mathrm{H}_{2} \mathrm{O}$ (Alfa Aesar, 98+ \%), and glycine (Junsei, $99 \%$ ) was concentrated by heating untill the dark-green gel was obtained. When the excess water was evaporated, the spontaneous ignition occurred, which converted the gel into an ash. The glycine/metal mole ratio was 1.5 . The ash was immediately fired at $1100{ }^{\circ} \mathrm{C}$ for 8 h. The X-ray diffraction patterns show the typical peaks corresponding to a perovskite oxide LSCM structure.

Thin LSCM film preparation. Polycrystalline LSCM thin films on the $\mathrm{Al}_{2} \mathrm{O}_{3}$ substrate were prepared by the means of PLD from the oxide target of the respective material. After obtaining LSCM powders, uniaxial pressing at $30 \mathrm{MPa}$ was followed by cold isostatic pressing at 290 MPa. The oxide targets were obtained after sintering at $1300{ }^{\circ} \mathrm{C}$ for $8 \mathrm{~h}$. The polycrystalline thin films with the thickness of $500 \mathrm{um}$ were prepared via PLD on single crystalline $\mathrm{Al}_{2} \mathrm{O}_{3}$ (0001) substrates (Dasom RMS, Korea), with a size of $10 \times 10 \times 0.65 \mathrm{~mm}^{3}$. The PLD system was operated with $\mathrm{KrF}$ excimer laser (Coherent COMPex Pro 205) emitting at the wavelength of $248 \mathrm{~nm}$ using the pulsed laser energy of $300 \mathrm{~mJ}$ with a repetition rate of $20 \mathrm{~Hz}$. During the ablation process, the substrate temperature and oxygen partial pressure were kept at $700{ }^{\circ} \mathrm{C}$ and 10 mTorr, respectively. After the deposition process, samples were annealed in air at $700{ }^{\circ} \mathrm{C}$ for an hour for the crystallization.

Electrical conductivity relaxation measurement. For the conductivity measurement of LSCM films, two platinum electrodes were applied on the LSCM films with $200 \mathrm{~nm}$ thickness and $2 \mathrm{~mm}$ distance by DC magnetron sputtering (with DC power of $10 \mathrm{~W}$, a working pressure of $10 \mathrm{mTorr}$ under a flow rate of $30 \mathrm{sccm} \mathrm{Ar}$, a deposition rate of $60 \mathrm{~nm} \mathrm{~min} \mathrm{~m}^{-1}$ ) using a metal shadow mask. A tube furnace with a K-type thermocouple was used for measurement at 650 
${ }^{\circ} \mathrm{C}$ under $1.3 \cdot 10^{-21} \mathrm{~atm}$ with the total flow rate of $190 \mathrm{sccm}$ controlled by a mass flow controller. The samples were first kept at equilibrium and the $\mathrm{pO}_{2}$ was abruptly changed with the fourway valve at a constant temperature. In-plane conductivity, which reflects the oxygen content in the samples, was measured for every 0.1 seconds until the sample adapts to the new equilibrium with applying DC across the length of the specimen and measured the voltage with chronopotentiometry (CP, VSP-300, Biologic). Both the oxidation and reduction directions of the measurement were carried for each condition in order to justify the assumption of the first order surface oxygen exchange reaction. The normalized conductivity as a function of time was fitted to a solution of the first order surface oxygen exchange reaction equation using the Origin program as follow:

$$
\frac{\sigma(t)-\sigma(0)}{\sigma(\infty)-\sigma(0)}=1-\exp \left(-\frac{k_{s}}{a} t\right)
$$

where $\sigma(t)$ is the electrical conductivity at time $\mathrm{t}, k_{s}$ is the surface reaction rate constant, and $a$ is the thickness of the sample

Electrochemical measurement. Electrochemical analyses of symmetric cells with bare and $\mathrm{Pt}$ nanoparticle-deposited LSCM with and without ALD were carried out using the AC impedance spectroscopy (ACIS, VSP-300, Biologic). The cells were located inside a continuous-flow alumina tube for test into which wet $\left(2 \% \mathrm{H}_{2} \mathrm{O}\right) \mathrm{CH}_{4}$ were delivered through digital mass flow controllers. Impedance spectra were obtained at $650{ }^{\circ} \mathrm{C}$ with the $\mathrm{AC}$ amplitude of $20 \mathrm{mV}$ in a frequency range of $1 \mathrm{MHz}$ to $0.1 \mathrm{mHz}$. 


\section{Section S3. Element analysis}

Figure S1 shows STEM images of Pt nanoparticles at the surface of LSCM support. The corresponding elemental mappings for $\mathrm{Pt}, \mathrm{Al}$, and La cations are given in Figure $1 \mathrm{~b}$-d. According to STEM characterization the thickness of Al oxide layer is around $2 \mathrm{~nm}$ which is in good agreement with ellipsometry results. The elemental mapping for Al shows the increased signal at the particles surface which was expected since the Al oxide layer is deposit uniformly at the surface of LSCM/Pt and uniform Al signal is expected. However the particle surface the EDS signal is not blocked by relatively thick LSCM particles thus Al signal is more intense at the particle edges.
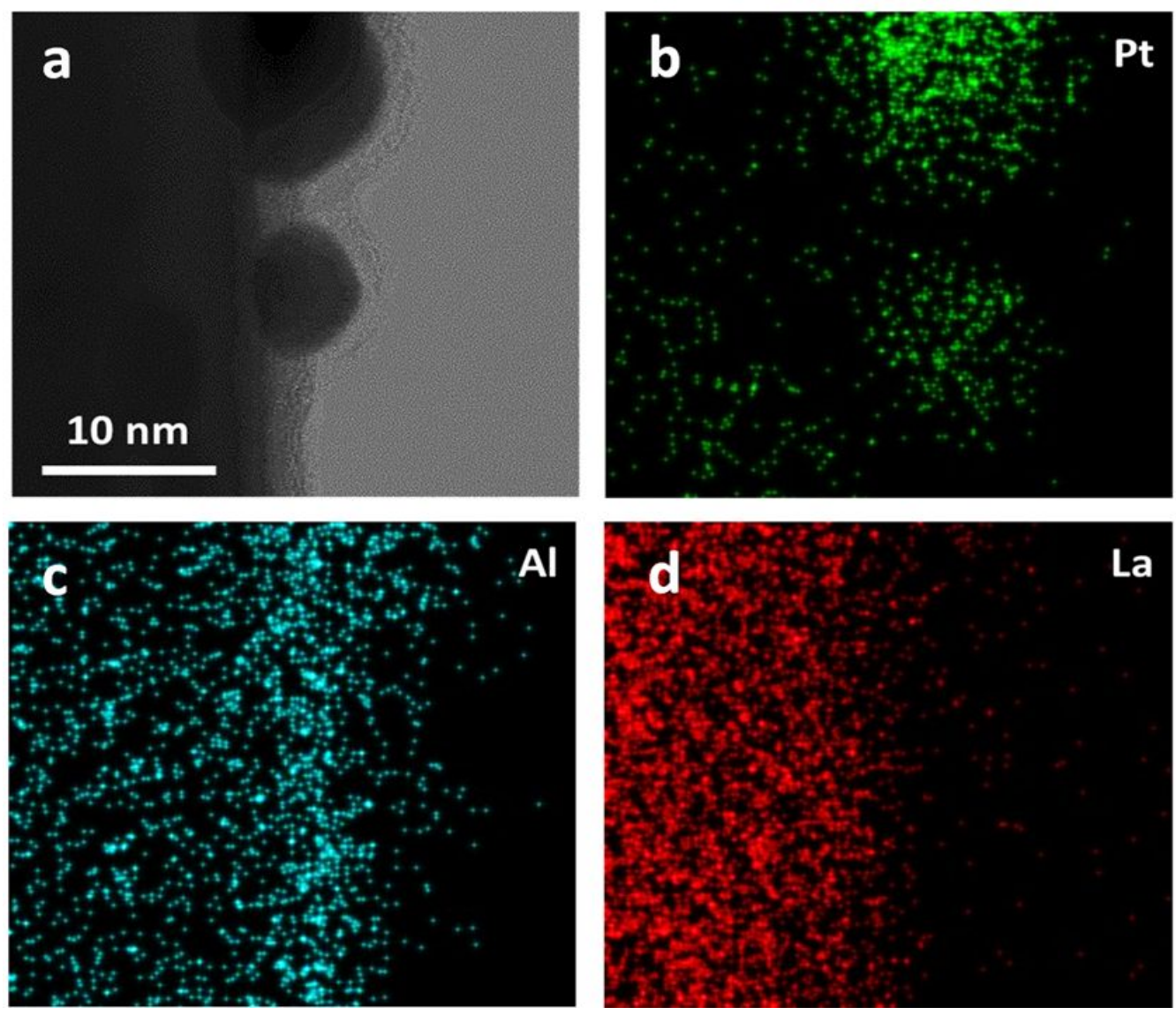

Figure S1. TEM images and elemental mapping. (a) The TEM image of Pt decorated $\mathrm{La}_{0.75} \mathrm{Sr}_{0.25} \mathrm{Cr}_{0.5} \mathrm{Mn}_{0.5} \mathrm{O}_{3}$ with $\mathrm{Al}_{2} \mathrm{O}_{3}$ coating. The elemental maps of (b) $\mathrm{Pt}$, (c) $\mathrm{Al}$, and (d) $\mathrm{La}$. 


\section{Section S4. ALD growth behavior}

Figure $\mathrm{S} 2$ is a graph showing the growth rate of $\mathrm{Al}_{2} \mathrm{O}_{3}$ vs. the pulsing time of precursor $\left(\mathrm{C}_{6} \mathrm{H}_{18} \mathrm{Al}_{2}\right)$. When the pulsing time is more than $0.5 \mathrm{~s}$, the growth rate remains constant and this means that self-limiting growth occurs. Thus, in this study, the pulsing time of $0.5 \mathrm{~s}$ is used.

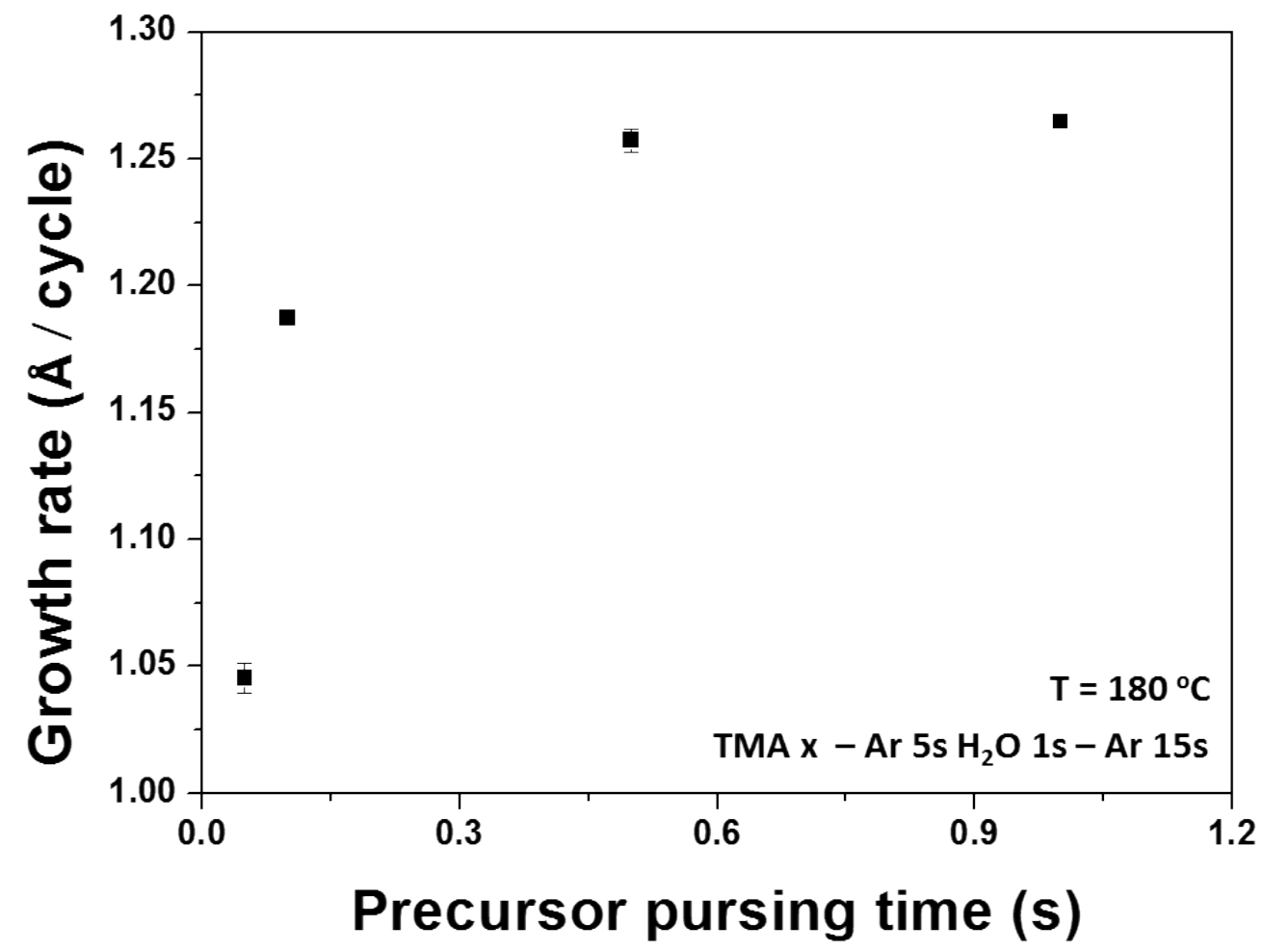

Figure S2. The growth rate per cycle as a function of the precursor pulse time. 


\section{Section S5. Electronic structure characterization}

After the Pt and Al oxide layer deposition the samples were analyzed by XPS measurements. On the survey scans, both $\mathrm{La}, \mathrm{Sr}, \mathrm{Mn}, \mathrm{Cr}, \mathrm{Al}$, and Pt peaks are clearly visible although there is some overlapping between $\mathrm{Al}$ and $\mathrm{Pt}$ peaks. The quantitative analysis revealed that the $(\mathrm{La}+\mathrm{Sr}) /(\mathrm{Co}+\mathrm{Mn})$ and $\mathrm{La} / \mathrm{Sr}$ ratios are close to stoichiometric ratios of $1 / 1$ and 3/1, respectively. After the deposition of $\mathrm{Pt}$ and $\mathrm{Al}_{2} \mathrm{O}_{3}$, Pt and $\mathrm{Al}$ peaks were observed in the spectra, but the $(\mathrm{La}+\mathrm{Sr}) /(\mathrm{Co}+\mathrm{Mn})$ and $\mathrm{La} / \mathrm{Sr}$ ratios remained identical to those in the bare LSCM sample.

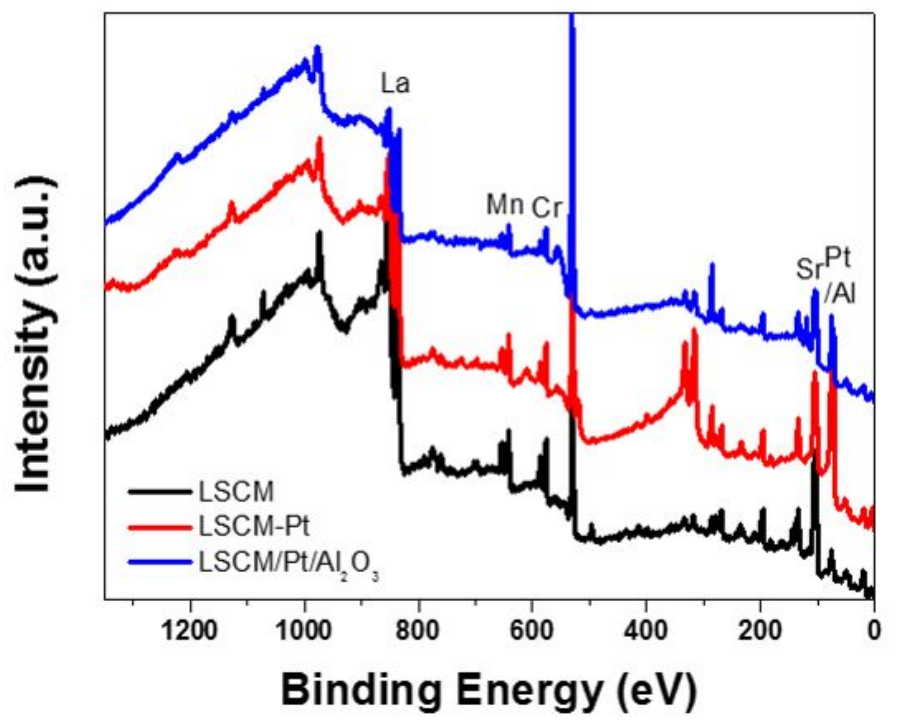

Figure S3. The XPS survey scans of LSCM, LSCM/Pt and LSCM/Pt/Al $\mathrm{AO}_{3}$ samples.

The In-situ XPS analysis at $650^{\circ} \mathrm{C}$ was used to evaluate the effect of $\mathrm{Pt}$ and $\mathrm{Al}$ oxide deposition on the Cr oxidation state. As it was expected upon deposition of the Pt NPs and Al oxide the Cr signal is decreasing since deposition of the Pt NPs and Al oxide at the surface screens out the photoelectron emission from LSCM particles. The deconvolution of the $\mathrm{Cr} 2 \mathrm{p}$ spectra reveals 2 peaks in the core-level spectra attributed to the $\mathrm{Cr}^{3+}$ and $\mathrm{Cr}^{4+}$ oxidation states. We have observed that the $\mathrm{Cr}^{3+} / \mathrm{Cr}^{4}$ ratio remains almost unchangeable upon Pt NPS and Al oxide deposition. 

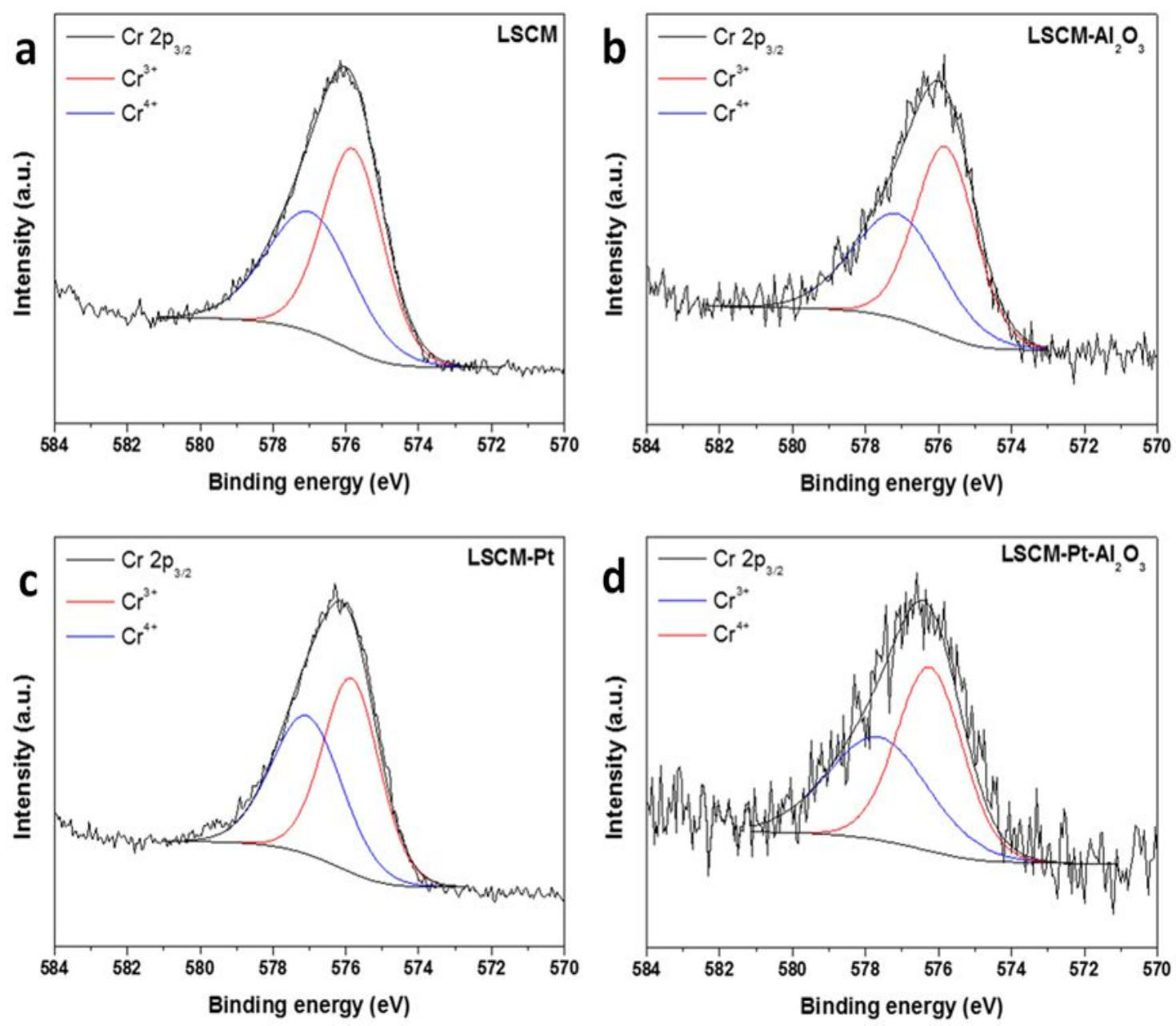

Figure S4. The deconvolution of the $\mathrm{Cr} 2 \mathrm{p}$ core-level peak spectra. Those recorded from (a) LSCM,(b) $\mathrm{LSCM} / \mathrm{Al}_{2} \mathrm{O}_{3}$, (c) LSCM/Pt, and (d) $\mathrm{LSCM} / \mathrm{Pt} / \mathrm{Al}_{2} \mathrm{O}_{3}$ samples. 


\section{Section S6. Influence of Pt nanocatalyst and $\mathrm{Al}_{2} \mathrm{O}_{3}$ coating on EIS performance}

Figure S5 shows the electrode activity of pristine $\mathrm{LSCM}, \mathrm{Al}_{2} \mathrm{O}_{3}$-coated LSCM electrodes Bare Pt, and $1.5 \mathrm{~nm} \mathrm{Al}_{2} \mathrm{O}_{3} / \mathrm{Pt}$ samples obtained in a wet $\left(2 \% \mathrm{H}_{2} \mathrm{O}\right) \mathrm{H}_{2}$ atmosphere. The activation energy is observed to be constant regardless of the presence of the $\mathrm{Al}_{2} \mathrm{O}_{3}$ layer, whereas the absolute electrode activity is reduced by the coating layers. These observations confirm that the $\mathrm{Al}_{2} \mathrm{O}_{3}$ layer is inert toward the $\mathrm{H}_{2}$ electrochemical oxidation reaction. On the other hand, Pt decorated samples show the reduced activation energies compared to the pristine LSCM, indicating that the Pt nanocatalyst acts as an electrochemical catalyst for $\mathrm{H}_{2}$ oxidation.

In addition, by observing the change in electrode reactivity with or without the $\mathrm{Al}_{2} \mathrm{O}_{3}$ coating, we could estimate the effect of the sintering of the catalysts. As shown in Figure S5, the initial electrode activity values at $650^{\circ} \mathrm{C}$ for the bare $\mathrm{Pt}$ sample and for the $1.5 \mathrm{~nm}-\mathrm{Al}_{2} \mathrm{O}_{3} / \mathrm{Pt}$ sample are $0.48 \mathrm{Scm}^{-2}$ and $0.45 \mathrm{Scm}^{-2}$, respectively. They appear to have similar reactivity to hydrogen, but considering that the approximately $84 \%$ of the Pt surface is covered with the coating layer, it can be estimated that the reactivity of the LSCM electrode containing the Pt catalysts is reduced by approximately $83 \%$ merely by the sintering of the catalysts. This calculation is only a very rough estimate, but nearly 20 -fold decrease in the electrode reactivity in the $\mathrm{CH}_{4}$ atmosphere supports that the coking of the catalyst is a more significant cause of the degradation. 


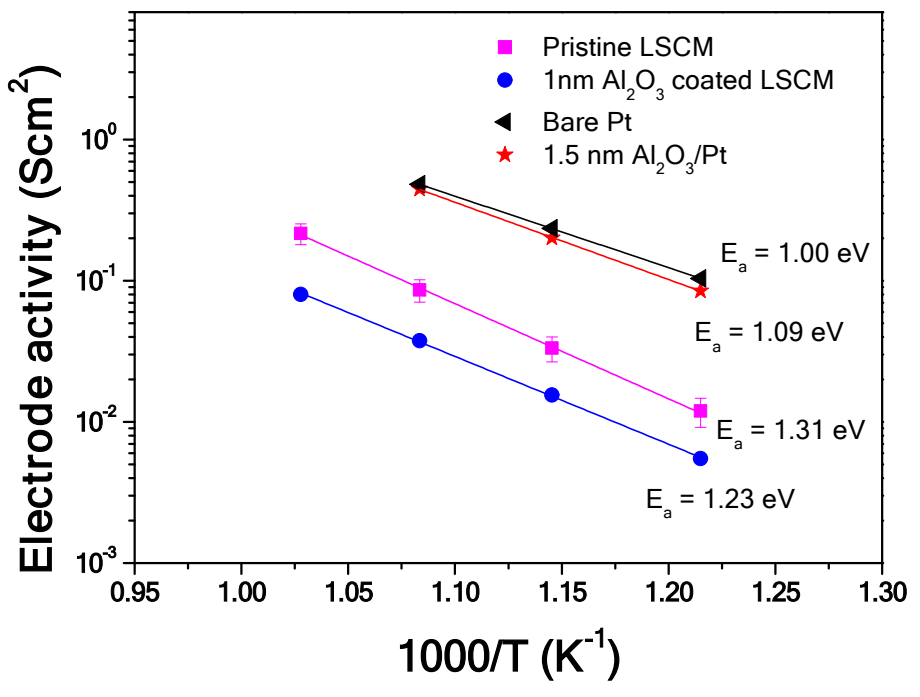

Figure S5. The temperature dependence of the electrode activity values of pristine LSCM, 1 $\mathrm{nm}$ of $\mathrm{Al}_{2} \mathrm{O}_{3}$ coated LSCM, Bare Pt and $1.5 \mathrm{~nm} \mathrm{Al} \mathrm{O}_{3} / \mathrm{Pt}$ samples in a wet $\left(2 \% \mathrm{H}_{2} \mathrm{O}\right) \mathrm{H}_{2}$ atmosphere. 


\section{Section S7. XRD results of a target and a thin film}

Figure S6 is the XRD spectra of the PLD target and thin film used in this study. It can be confirmed that the $\mathrm{La}_{0.75} \mathrm{Sr}_{0.25} \mathrm{Cr}_{0.5} \mathrm{Mn}_{0.5} \mathrm{O}_{3}$ (LSCM) thin film with a rhombohedral perovskite structure is grown.
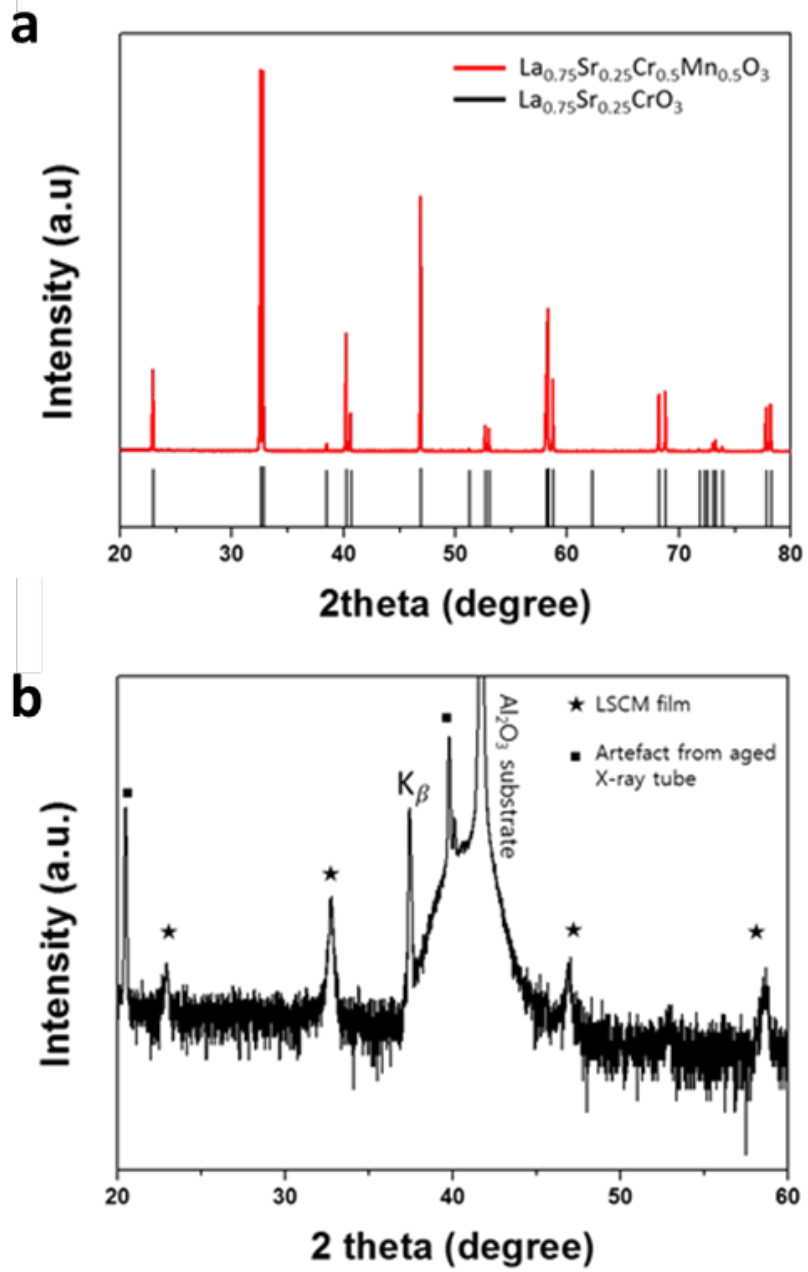

Figure S6. The X-ray diffraction (XRD) patterns. Those for (a) the prepared LSCM powder and (b) the LSCM thin film grown on a single-crystal $\mathrm{Al}_{2} \mathrm{O}_{3}(0001)$ substrate. 


\section{Section S8. Influence of $\mathrm{Al}_{2} \mathrm{O}_{3}$ coating on surface oxygen exchange kinetic and estimation of surface coverage}

Figure S7 presents the relaxation profiles of $\mathrm{La}_{0.75} \mathrm{Sr}_{0.25} \mathrm{Cr}_{0.5} \mathrm{Mn}_{0.5} \mathrm{O}_{3}$ (LSCM) films, showing the transient behavior of the conductivity with a step change in the $\mathrm{pO}_{2}$ of the surrounding gas. In order to avoid morphological complications, flat and dense poly-crystalline LSCM thin films were prepared as model samples via pulse laser deposition (PLD) (Figure S6), and the oxygen exchange rates using a $\mathrm{H}_{2} / \mathrm{H}_{2} \mathrm{O}$ buffer mixture gas depending on the deposited thickness of $\mathrm{Al}_{2} \mathrm{O}_{3}$ were monitored via $\mathrm{ECR}$ at the electrode operating temperature of $650^{\circ} \mathrm{C}$. The normalized conductivity of LSCM thin films on $\mathrm{Al}_{2} \mathrm{O}_{3}$ substrate at $650^{\circ} \mathrm{C}$ with switching $\mathrm{pO}_{2}$ from $4.4 \times 10^{-22}$ atm to $2.12 \times 10^{-21} \mathrm{~atm}$. Given that the LSCM film thickness is very thin to ignore the bulk diffusion of oxygen ions through the film and $\mathrm{Al}_{2} \mathrm{O}_{3}$ is not reactive, the evolution of conductivity relaxation profiles over time reflects the surface response and is expected to be proportional to the exposed surface area of the LSCM electrode or uncovered area by $\mathrm{Al}_{2} \mathrm{O}_{3}$. As the thickness of the deposited $\mathrm{Al}_{2} \mathrm{O}_{3}$ layer increases, the relaxation response slows and the oxygen exchange rate decreases accordingly. However, even the thickest $3 \mathrm{~nm}$ $\mathrm{Al}_{2} \mathrm{O}_{3}$ layer exhibits much faster relaxation than clean $\mathrm{Al}_{2} \mathrm{O}_{3}$, which means that the surface of the LSCM thin film is not fully passivated. 


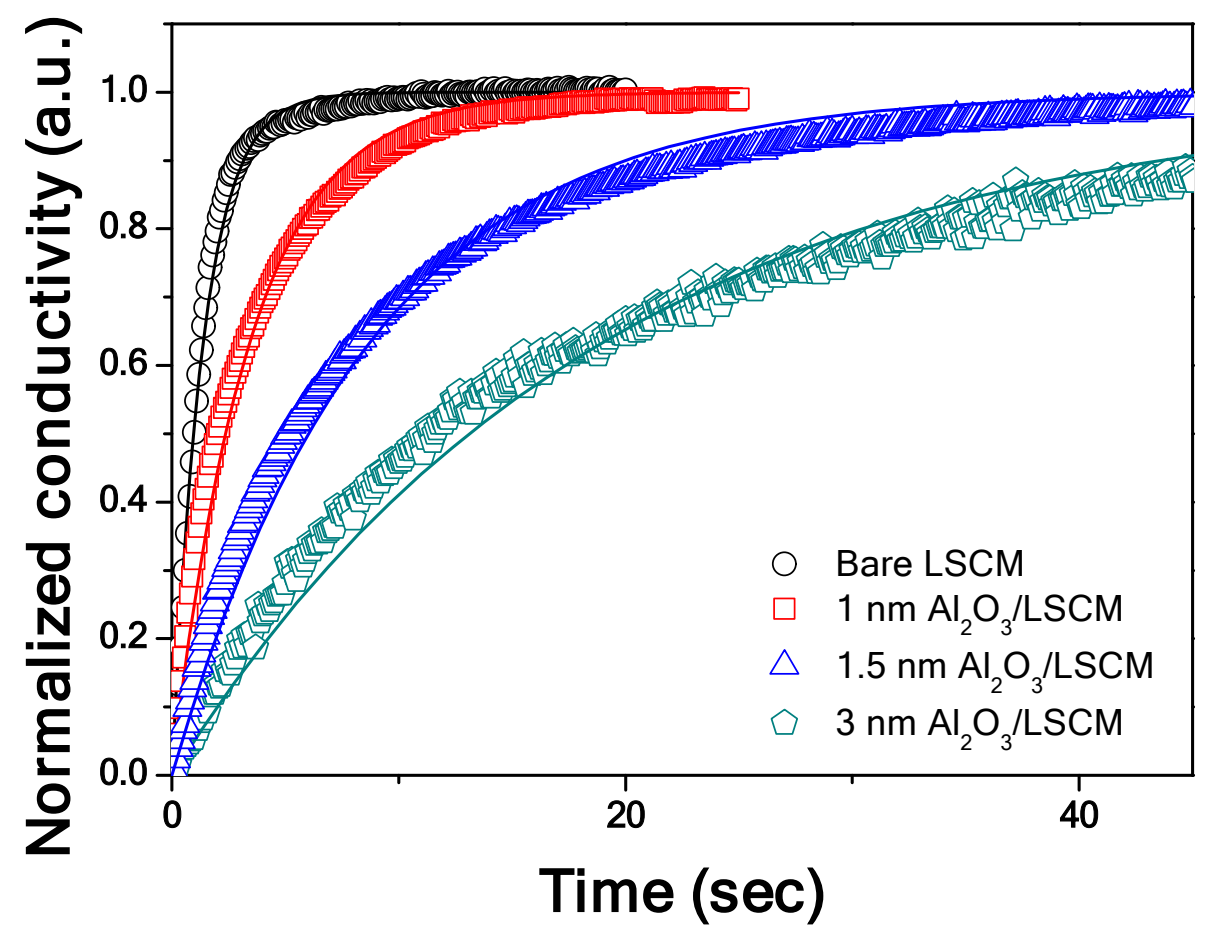

Figure S7. The normalized conductivity of a polycrystalline LSCM thin film on the $\mathrm{Al}_{2} \mathbf{O}_{3}$ substrate. It is notable that the corresponding temperate and partial pressures for oxygen are set at $650^{\circ} \mathrm{C}$ and $\mathrm{pO}_{2}=1.3 \times 10^{-21} \mathrm{~atm}\left(\Delta \mathrm{pO}_{2}=4.4 \times 10^{-22} \mathrm{~atm}\right.$ to $\left.2.12 \times 10^{-21} \mathrm{~atm}\right)$, respectively.

The degree to which the $\mathrm{k}$ value decreases with the $\mathrm{Al}_{2} \mathrm{O}_{3}$ coating thickness predicted how much the surface of the LSCM thin film was covered by $\mathrm{Al}_{2} \mathrm{O}_{3}$, and the results are shown in table S3. With the increase in the thickness of the $\mathrm{Al}_{2} \mathrm{O}_{3}$ layer, the coverage is determined to change from $60 \%$ for the 1.0 -nm-thick $\mathrm{Al}_{2} \mathrm{O}_{3}$ film to $93 \%$ for the 3.0 -nm-thick film, confirming that the ALD layer does not completely passivate the electrode surface. The incomplete coverage of the LSCM surface with the $\mathrm{Al}_{2} \mathrm{O}_{3}$ layer even with the 3.0-nm-thick film can be explained by the fact that the ALD layer heat-treated at $650^{\circ} \mathrm{C}$ is porous and gas permeable, which is attributed to the removal of residual carbon species and Oswald ripening at high temperatures. 


\begin{tabular}{ccc}
\hline Samples & $\mathbf{k}_{\mathrm{s}}\left(\mathbf{c m} \cdot \mathbf{s e c}^{-1}\right)$ & Coverage \\
\hline Bare LSCM & $7.3 \cdot 10^{-6}$ & - \\
$1 \mathrm{~nm} \mathrm{LSCM}$ & $2.9 \cdot 10^{-6}$ & $60 \%$ \\
$1.5 \mathrm{~nm} \mathrm{LSCM}$ & $1.2 \cdot 10^{-6}$ & $84 \%$ \\
$3 \mathrm{~nm} \mathrm{LSCM}$ & $5.3 \cdot 10^{-7}$ & $93 \%$ \\
\hline
\end{tabular}

Table S3 The summary of surface oxygen exchange coefficient $\left(\mathrm{k}_{\mathrm{s}}\right)$ and surface coverage values from $\mathrm{k}_{\mathrm{s}}$. 


\section{Section S9. Stability of Pt nanoparticles}

Figure S8 is the SEM images showing Pt NPs dispersed on the $\mathrm{La}_{0.75} \mathrm{Sr}_{0.25} \mathrm{Cr}_{0.5} \mathrm{Mn}_{0.5} \mathrm{O}_{3}$ depending on the thickness of $\mathrm{Al}_{2} \mathrm{O}_{3}$ overcoat after heat treatment.
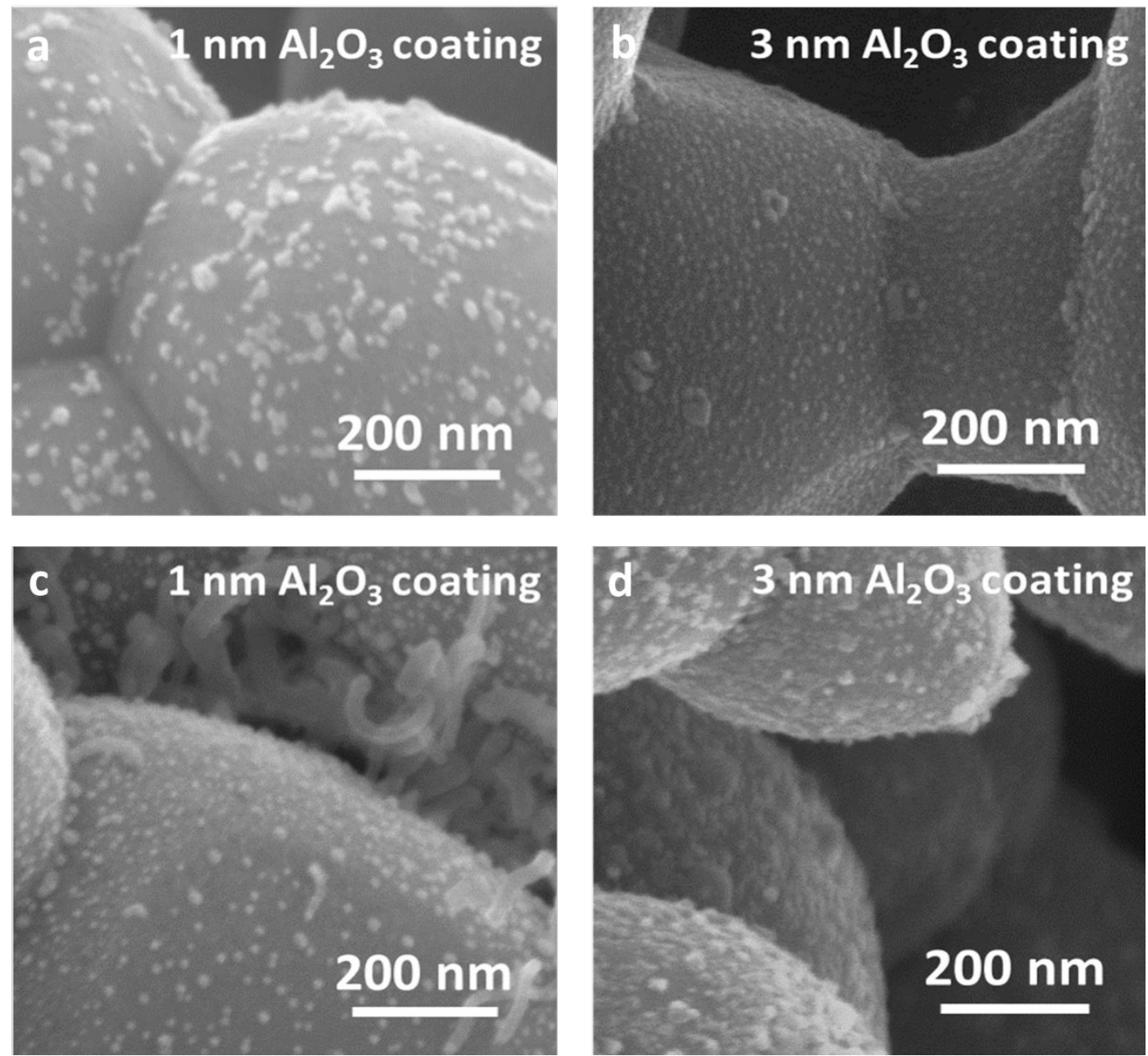

Figure S8. The SEM images of $\mathrm{LSCM} / \mathrm{Pt}$ with different $\mathrm{Al}_{2} \mathrm{O}_{3}$ coating layers after sintering and carbon coking. Those for (a) $1 \mathrm{~nm}$ and (b) $3 \mathrm{~nm} \mathrm{Al}{ }_{2} \mathrm{O}_{3}$ coating layer thicknesses after sintering at $700^{\circ} \mathrm{C}$ for $1 \mathrm{~h}$ under air. Those for (c) $1 \mathrm{~nm}$ and (d) $3 \mathrm{~nm} \mathrm{Al}_{2} \mathrm{O}_{3}$ coating layer thicknesses after carbon coking at $650^{\circ} \mathrm{C}$ for $25 \mathrm{~h}$ under wet $\left(2 \% \mathrm{H}_{2} \mathrm{O}\right) \mathrm{CH}_{4}$. 


\section{Section S10. References}

(1) McNeary, W. W.; Zaccarine, S. F.; Lai, A.; Linico, A. E.; Pylypenko, S.; Weimer, A. W., Improved Durability and Activity of Pt/C Catalysts through Atomic Layer Deposition of Tungsten Nitride and Subsequent Thermal Treatment. Applied Catalysis B: Environmental 2019, 254, 587-593.

(2) Jackson, D. H.; Schwartz, M. M.; Ngo, C.; Facteau, D.; Pylypenko, S.; Marshall, C. L.; Dameron, A. A., Hydrocarbon Catalyzed-Selective Catalytic Reduction Catalysts Using CoreShell Atomic Layer Deposited $\mathrm{CeO}_{2}$ and $\mathrm{ZrO}_{2}$. Journal of Vacuum Science \& Technology A: Vacuum, Surfaces, and Films 2019, 37 (2), 020919.

(3) Sudheeshkumar, V.; Lushington, A.; Sun, X.; Scott, R. W., Thermal Stability of AluminaOvercoated Au25 Clusters for Catalysis. ACS Applied Nano Materials 2018, 1 (12), 6904-6911. (4) Wu, L.; Eberhart, M.; Nayak, A.; Brennaman, M. K.; Shan, B.; Meyer, T. J., A Molecular Silane-Derivatized Ru (II) Catalyst for Photoelectrochemical Water Oxidation. Journal of the American Chemical Society 2018, 140 (44), 15062-15069.

(5) Cai, J.; Zhang, J.; Cao, K.; Gong, M.; Lang, Y.; Liu, X.; Chu, S.; Shan, B.; Chen, R., Selective Passivation of Pt Nanoparticles with Enhanced Sintering Resistance and Activity toward CO Oxidation via Atomic Layer Deposition. ACS Applied Nano Materials 2018, 1 (2), $522-530$.

(6) Yang, N.; Yoo, J. S.; Schumann, J.; Bothra, P.; Singh, J. A.; Valle, E.; Abild-Pedersen, F.; Nørskov, J. K.; Bent, S. F., Rh-MnO Interface Sites Formed by Atomic Layer Deposition Promote Syngas Conversion to Higher Oxygenates. ACS Catalysis 2017, 7 (9), 5746-5757.

(7) Liang, H.; Zhang, B.; Ge, H.; Gu, X.; Zhang, S.; Qin, Y., Porous $\mathrm{TiO}_{2} / \mathrm{Pt} / \mathrm{TiO}_{2}$ Sandwich Catalyst for Highly Selective Semihydrogenation of Alkyne to Olefin. ACS Catalysis 2017, 7 (10), 6567-6572.

(8) Hu, Q.; Wang, S.; Gao, Z.; Li, Y.; Zhang, Q.; Xiang, Q.; Qin, Y., The Precise Decoration 
of Pt Nanoparticles with Fe Oxide by Atomic Layer Deposition for the Selective Hydrogenation of Cinnamaldehyde. Applied Catalysis B: Environmental 2017, 218, 591-599.

(9) Yi, H.; Xia, Y.; Yan, H.; Lu, J., Coating Pd/ $\mathrm{Al}_{2} \mathrm{O}_{3}$ Catalysts with $\mathrm{FeO}_{\mathrm{x}}$ Enhances Both Activity and Selectivity in 1, 3-Butadiene Hydrogenation. Chinese Journal of Catalysis 2017, $38(9), 1581-1587$.

(10) Zhang, J.; Yu, Z.; Gao, Z.; Ge, H.; Zhao, S.; Chen, C.; Chen, S.; Tong, X.; Wang, M.; Zheng, Z., Porous $\mathrm{TiO}_{2}$ Nanotubes with Spatially Separated Platinum and $\mathrm{CoO}_{\mathrm{x}}$ Cocatalysts Produced by Atomic Layer Deposition for Photocatalytic Hydrogen Production. Angewandte Chemie International Edition 2017, 56 (3), 816-820.

(11) Lei, Y.; Lee, S.; Low, K.-B.; Marshall, C. L.; Elam, J. W., Combining Electronic and Geometric Effects of ZnO-Promoted Pt Nanocatalysts for Aqueous Phase Reforming of 1Propanol. ACS Catalysis 2016, 6 (6), 3457-3460.

(12) Wang, C.; Wang, H.; Yao, Q.; Yan, H.; Li, J.; Lu, J., Precisely Applying $\mathrm{TiO}_{2}$ Overcoat on Supported Au Catalysts Using Atomic Layer Deposition for Understanding the Reaction Mechanism and Improved Activity in CO Oxidation. The Journal of Physical Chemistry C 2015, $120(1), 478-486$.

(13) Ge, H.; Zhang, B.; Gu, X.; Liang, H.; Yang, H.; Gao, Z.; Wang, J.; Qin, Y., A Tandem Catalyst with Multiple Metal Oxide Interfaces Produced by Atomic Layer Deposition. Angewandte Chemie International Edition 2016, 55 (25), 7081-7085.

(14) Yi, H.; Du, H.; Hu, Y.; Yan, H.; Jiang, H.-L.; Lu, J., Precisely Controlled Porous Alumina Overcoating on Pd Catalyst by Atomic Layer Deposition: Enhanced Selectivity and Durability in Hydrogenation of 1,3-Butadiene. Acs Catalysis 2015, 5 (5), 2735-2739.

(15) Kim, H. J.; Jackson, D. H.; Lee, J.; Guan, Y.; Kuech, T. F.; Huber, G. W., Enhanced Activity and Stability of $\mathrm{TiO}_{2}$-Coated Cobalt/Carbon Catalysts for Electrochemical Water Oxidation. Acs Catalysis 2015, 5 (6), 3463-3469. 
(16) Onn, T. M.; Zhang, S.; Arroyo-Ramirez, L.; Chung, Y.-C.; Graham, G. W.; Pan, X.;

Gorte, R. J., Improved Thermal Stability and Methane-Oxidation Activity of $\mathrm{Pd} / \mathrm{Al}_{2} \mathrm{O}_{3}$ Catalysts by Atomic Layer Deposition of $\mathrm{ZrO}_{2}$. ACS Catalysis 2015, 5 (10), 5696-5701.

(17) Zhang, H.; Canlas, C.; Kropf, A. J.; Elam, J. W.; Dumesic, J. A.; Marshall, C. L., Enhancing the Stability of Copper Chromite Catalysts for the Selective Hydrogenation of Furfural with ALD Overcoating (II)-Comparison between $\mathrm{TiO}_{2}$ and $\mathrm{Al}_{2} \mathrm{O}_{3}$ Overcoatings. Journal of catalysis 2015, 326, 172-181.

(18) Lee, J.; Burt, S. P.; Carrero, C. A.; Alba-Rubio, A. C.; Ro, I.; O’Neill, B. J.; Kim, H. J.; Jackson, D. H.; Kuech, T. F.; Hermans, I., Stabilizing Cobalt Catalysts for Aqueous-Phase Reactions by Strong Metal-Support Interaction. Journal of catalysis 2015, 330, 19-27.

(19) Alba-Rubio, A. C.; O’Neill, B. J.; Shi, F.; Akatay, C.; Canlas, C.; Li, T.; Winans, R.; Elam, J. W.; Stach, E. A.; Voyles, P. M., Pore Structure and Bifunctional Catalyst Activity of Overlayers Applied by Atomic Layer Deposition on Copper Nanoparticles. Acs Catalysis 2014, $4(5), 1554-1557$.

(20) Zhang, H.; Gu, X. K.; Canlas, C.; Kropf, A. J.; Aich, P.; Greeley, J. P.; Elam, J. W.; Meyers, R. J.; Dumesic, J. A.; Stair, P. C., Atomic Layer Deposition Overcoating: Tuning Catalyst Selectivity for Biomass Conversion. Angewandte Chemie International Edition 2014, 53 (45), 12132-12136.

(21) O'Neill, B. J.; Miller, J. T.; Dietrich, P. J.; Sollberger, F. G.; Ribeiro, F. H.; Dumesic, J. A., Operando X-ray Absorption Spectroscopy Studies of Sintering for Supported Copper Catalysts during Liquid-phase Reaction. ChemCatChem 2014, 6 (9), 2493-2496.

(22) Lee, J.; Jackson, D. H.; Li, T.; Winans, R. E.; Dumesic, J. A.; Kuech, T. F.; Huber, G. W., Enhanced Stability of Cobalt Catalysts by Atomic Layer Deposition for Aqueous-Phase Reactions. Energy \& Environmental Science 2014, 7 (5), 1657-1660.

(23) Marshall, C. L.; Zhang, H. B.; Kropf, A. J.; Zhang, G. H.; Elam, J. W.; Miller, J. T.; 
Sollberger, F.; Ribeiro, F.; Stach, E. A.; Dumesic, J. A., Enhancing the Stability of Copper Chromite Catalysts for the Selective Hydrogenation of Furfural Using ALD Overcoating. Abstr. Pap. Am. Chem. Soc. 2014, $248,1$.

(24) O'Neill, B. J.; Jackson, D. H.; Crisci, A. J.; Farberow, C. A.; Shi, F.; Alba-Rubio, A. C.;

Lu, J.; Dietrich, P. J.; Gu, X.; Marshall, C. L., Stabilization of Copper Catalysts for Liquid-Phase Reactions by Atomic Layer Deposition. Angewandte Chemie International Edition 2013, 52 (51), 13808-13812.

(25) Seo, H. O.; Sim, J. K.; Kim, K.-D.; Kim, Y. D.; Lim, D. C.; Kim, S. H., Carbon Dioxide Reforming of Methane to Synthesis Gas over a $\mathrm{TiO}_{2}-\mathrm{Ni}$ Inverse Catalyst. Applied Catalysis A: General 2013, 451, 43-49.

(26) Lobo, R.; Marshall, C. L.; Dietrich, P. J.; Ribeiro, F. H.; Akatay, C.; Stach, E. A.; Mane, A.; Lei, Y.; Elam, J.; Miller, J. T., Understanding the Chemistry of $\mathrm{H}_{2}$ Production for 1Propanol Reforming: Pathway and Support Modification Effects. ACS Catalysis 2012, 2 (11), $2316-2326$.

(27) Lu, J.; Liu, B.; Greeley, J. P.; Feng, Z.; Libera, J. A.; Lei, Y.; Bedzyk, M. J.; Stair, P. C.; Elam, J. W., Porous Alumina Protective Coatings on Palladium Nanoparticles by SelfPoisoned Atomic Layer Deposition. Chemistry of Materials 2012, 24 (11), 2047-2055.

(28) Lu, J.; Fu, B.; Kung, M. C.; Xiao, G.; Elam, J. W.; Kung, H. H.; Stair, P. C., Coking-and Sintering-Resistant Palladium Catalysts Achieved through Atomic Layer Deposition. Science 2012, 335 (6073), 1205-1208.

(29) Feng, H.; Lu, J.; Stair, P. C.; Elam, J. W., Alumina Over-Coating on Pd Nanoparticle Catalysts by Atomic Layer Deposition: Enhanced Stability and Reactivity. Catalysis Letters 2011, $141(4), 512-517$.

(30) Kim, D. W.; Kim, K.-D.; Seo, H. O.; Dey, N. K.; Kim, M. J.; Kim, Y. D.; Lim, D. C.; Lee, K. H., $\mathrm{TiO}_{2} / \mathrm{Ni}$ Inverse-Catalysts Prepared by Atomic Layer Deposition (ALD). Catalysis 
letters 2011, 141 (6), 854-859.

(31) Ma, Z.; Brown, S.; Howe, J. Y.; Overbury, S. H.; Dai, S., Surface Modification of $\mathrm{Au} / \mathrm{TiO}_{2}$ catalysts by $\mathrm{SiO}_{2}$ via Atomic Layer Deposition. The Journal of Physical Chemistry C 2008, $112(25), 9448-9457$.

(32) Karimaghaloo, A.; Andrade, A. M.; Grewal, S.; Shim, J. H.; Lee, M. H., Mechanism of Cathodic Performance Enhancement by a Few-Nanometer-Thick Oxide Overcoat on Porous Pt Cathodes of Solid Oxide Fuel Cells. ACS Omega 2017, 2 (3), 806-813.

(33) Zhou, K.; Fan, X.; Wei, X.; Liu, J., The Strategies of Advanced Cathode Composites for Lithium-Sulfur Batteries. Science China Technological Sciences 2017, 60 (2), 175-185.

(34) Chang, I.; Kim, D.; Lee, Y.; Hong, S.-H.; Cha, S. W., Effect of Ultra-Thin $\mathrm{SnO}_{2}$ Coating on Pt Catalyst for Energy Applications. International Journal of Precision Engineering and Manufacturing 2016, 17 (5), 691-694.

(35) Neoh, K. C.; Han, G. D.; Kim, M.; Kim, J. W.; Choi, H. J.; Park, S. W.; Shim, J. H., Nanoporous Silver Cathode Surface Treated by Atomic Layer Deposition of $\mathrm{CeO}_{\mathrm{x}}$ for LowTemperature Solid Oxide Fuel Cells. Nanotechnology 2016, 27 (18), 185403.

(36) Chang, I.; Ji, S.; Park, J.; Lee, M. H.; Cha, S. W., Ultrathin YSZ Coating on Pt Cathode for High Thermal Stability and Enhanced Oxygen Reduction Reaction Activity. Advanced Energy Materials 2015, 5 (10), 1402251.

(37) Liu, K.-Y.; Fan, L.; Yu, C.-C.; Su, P.-C., Thermal Stability and Performance Enhancement of Nano-Porous Platinum Cathode in Solid Oxide Fuel Cells by Nanoscale $\mathrm{ZrO}_{2}$ Capping. Electrochemistry Communications 2015, 56, 65-69.

(38) Li, Y. K.; Choi, H. J.; Kim, H. K.; Chean, N. K.; Kim, M.; Koo, J.; Jeong, H. J.; Jang, D. Y.; Shim, J. H., Nanoporous Silver Cathodes Surface-Treated by Atomic Layer Deposition of $\mathrm{Y}: \mathrm{ZrO}_{2}$ for High-Performance Low-Temperature Solid Oxide Fuel Cells. Journal of Power Sources 2015, 295, 175-181. 
(39) Gong, Y.; Patel, R. L.; Liang, X.; Palacio, D.; Song, X.; Goodenough, J. B.; Huang, K., Atomic Layer Deposition Functionalized Composite SOFC Cathode $\mathrm{La}_{0.6} \mathrm{Sr}_{0.4} \mathrm{Fe}_{0.8} \mathrm{Co}_{0.2} \mathrm{O}_{3-\delta^{-}}$ $\mathrm{Gd}_{0.2} \mathrm{Ce}_{0.8} \mathrm{O}_{1.9}$ : Enhanced Long-Term Stability. Chemistry of Materials 2013, 25 (21), 42244231.

(40) Gong, Y.; Palacio, D.; Song, X.; Patel, R. L.; Liang, X.; Zhao, X.; Goodenough, J. B.; Huang, K., Stabilizing Nanostructured Solid Oxide Fuel Cell Cathode with Atomic Layer Deposition. Nano letters 2013, 13 (9), 4340-4345.

(41) Jeong, H.; Kim, J. W.; Park, J.; An, J.; Lee, T.; Prinz, F. B.; Shim, J. H., Bimetallic Nickel/Ruthenium Catalysts Synthesized by Atomic Layer Deposition for Low-Temperature Direct Methanol Solid Oxide Fuel Cells. ACS applied materials \& interfaces 2016, 8 (44), 30090-30098.

(42) Jeong, H. J.; Kim, J. W.; Bae, K.; Jung, H.; Shim, J. H., Platinum-Ruthenium Heterogeneous Catalytic Anodes Prepared by Atomic Layer Deposition for Use in Direct Methanol Solid Oxide Fuel Cells. ACS Catalysis 2015, 5 (3), 1914-1921.

(43) Ahvenniemi, E.; Matvejeff, M.; Karppinen, M., Atomic Layer Deposition of Quaternary Oxide (La,Sr) $\mathrm{CoO}_{3-\delta}$ Thin Films. Dalton Transactions 2015, 44 (17), 8001-8006.

(44) Jeong, H. J.; Kim, J. W.; Jang, D. Y.; Shim, J. H., Atomic Layer Deposition of Ruthenium Surface-Coating on Porous Platinum Catalysts for High-Performance Direct Ethanol Solid Oxide Fuel Cells. Journal of Power Sources 2015, 291, 239-245.

(45) Choi, H. J.; Bae, K.; Jang, D. Y.; Kim, J. W.; Shim, J. H., Performance Degradation of Lanthanum Strontium Cobaltite after Surface Modification. Journal of The Electrochemical Society 2015, 162 (6), F622-F626.

(46) Ji, S.; Chang, I.; Cho, G. Y.; Lee, Y. H.; Shim, J. H.; Cha, S. W., Application of Dense Nano-Thin Platinum Films for Low-Temperature Solid Oxide Fuel Cells by Atomic Layer Deposition. international journal of hydrogen energy 2014, 39 (23), 12402-12408. 
(47) Anthony, S. Y.; Küngas, R.; Vohs, J. M.; Gorte, R. J., Modification of SOFC Cathodes by Atomic Layer Deposition. Journal of The Electrochemical Society 2013, 160 (11), F1225F1231.

(48) An, J.; Kim, Y.-B.; Prinz, F. B., Ultra-Thin Platinum Catalytic Electrodes Fabricated by Atomic Layer Deposition. Physical Chemistry Chemical Physics 2013, 15 (20), 7520-7525.

(49) Chao, C. C.; Motoyama, M.; Prinz, F. B., Nanostructured Platinum Catalysts by Atomic-Layer Deposition for Solid-Oxide Fuel Cells. Advanced Energy Materials 2012, 2 (6), $651-654$

(50) Shim, J. H.; Jiang, X.; Bent, S. F.; Prinz, F. B., Catalysts with Pt Surface Coating by Atomic Layer Deposition for Solid Oxide Fuel Cells. Journal of the Electrochemical Society 2010, 157 (6), B793-B797.

(51) Lie, M.; Nilsen, O.; Fjellvåg, H.; Kjekshus, A., Growth of $\mathrm{La}_{1-\mathrm{x}} \mathrm{Sr}_{\mathrm{x}} \mathrm{FeO}_{3}$ Thin Films by Atomic Layer Deposition. Dalton Transactions 2009, (3), 481-489.

(52) Jiang, X.; Huang, H.; Prinz, F. B.; Bent, S. F., Application of Atomic Layer Deposition of Platinum to Solid Oxide Fuel Cells. Chemistry of materials 2008, 20 (12), 3897-3905.

(53) Holme, T. P.; Lee, C.; Prinz, F. B., Atomic Layer Deposition of LSM Cathodes for Solid Oxide Fuel Cells. Solid State Ionics 2008, 179 (27-32), 1540-1544.

(54) Nilsen, O.; Rauwel, E.; Fjellvåg, H.; Kjekshus, A., Growth of $\mathrm{La}_{1-\mathrm{x}} \mathrm{Ca}_{\mathrm{x}} \mathrm{MnO}_{3}$ Thin Films by Atomic Layer Deposition. Journal of Materials Chemistry 2007, 17 (15), 1466-1475.

(55) Li, Y.; Wang, S.; Su, P.-C., Proton-Conducting Micro-Solid Oxide Fuel Cells with Improved Cathode Reactions by a Nanoscale Thin Film Gadolinium-Doped Ceria Interlayer. Scientific reports 2016, 6, 22369.

(56) Ji, S.; Cho, G. Y.; Yu, W.; Su, P.-C.; Lee, M. H.; Cha, S. W., Plasma-Enhanced Atomic Layer Deposition of Nanoscale Yttria-Stabilized Zirconia Electrolyte for Solid Oxide Fuel Cells with Porous Substrate. ACS applied materials \& interfaces 2015, 7 (5), 2998-3002. 
(57) An, J.; Kim, Y.-B.; Park, J.; Gür, T. M.; Prinz, F. B., Three-Dimensional Nanostructured Bilayer Solid Oxide Fuel Cell with $1.3 \mathrm{~W} / \mathrm{cm}^{2}$ at 450 C. Nano letters 2013, 13 (9), 4551-4555. (58) Fan, Z.; Chao, C.-C.; Hossein-Babaei, F.; Prinz, F. B., Improving Solid Oxide Fuel Cells with Yttria-Doped Ceria Interlayers by Atomic Layer Deposition. Journal of Materials Chemistry 2011, 21 (29), 10903-10906.

(59) Ballée, E.; Ringuedé, A.; Cassir, M.; Putkonen, M.; Niinistö, L., Synthesis of a ThinLayered Ionic Conductor, $\mathrm{CeO}_{2}-\mathrm{Y}_{2} \mathrm{O}_{3}$, by Atomic Layer Deposition in View of Solid Oxide Fuel Cell Applications. Chemistry of Materials 2009, 21 (19), 4614-4619.

(60) Shim, J. H.; Park, J. S.; An, J.; Gür, T. M.; Kang, S.; Prinz, F. B., IntermediateTemperature Ceramic Fuel Cells with Thin Film Yttrium-Doped Barium Zirconate Electrolytes. Chemistry of Materials 2009, 21 (14), 3290-3296.

(61) Brahim, C.; Chauveau, F.; Ringuedé, A.; Cassir, M.; Putkonen, M.; Niinistö, L., $\mathrm{ZrO}_{2}-$ $\mathrm{In}_{2} \mathrm{O}_{3}$ Thin Layers with Gradual Ionic to Electronic Composition Synthesized by Atomic Layer Deposition for SOFC Applications. Journal of Materials Chemistry 2009, 19 (6), 760-766. (62) Chao, C.-C.; Kim, Y. B.; Prinz, F. B., Surface Modification of Yttria-Stabilized Zirconia Electrolyte by Atomic Layer Deposition. Nano letters 2009, 9 (10), 3626-3628.

(63) Su, P.-C.; Chao, C.-C.; Shim, J. H.; Fasching, R.; Prinz, F. B., Solid Oxide Fuel Cell with Corrugated Thin Film Electrolyte. Nano letters 2008, 8 (8), 2289-2292.

(64) Brahim, C.; Ringuede, A.; Cassir, M.; Putkonen, M.; Niinistö, L., Electrical Properties of Thin Yttria-Stabilized Zirconia Overlayers Produced by Atomic Layer Deposition for Solid Oxide Fuel Cell Applications. Applied Surface Science 2007, 253 (8), 3962-3968.

(65) Shim, J. H.; Chao, C.-C.; Huang, H.; Prinz, F. B., Atomic Layer Deposition of YttriaStabilized Zirconia for Solid Oxide Fuel Cells. Chemistry of Materials 2007, 19 (15), 38503854.

(66) Ginestra, C. N.; Sreenivasan, R.; Karthikeyan, A.; Ramanathan, S.; McIntyre, P. C., 
Atomic Layer Deposition of Y2O3/ ZrO2 Nanolaminates A Route to Ultrathin Solid-State Electrolyte Membranes. Electrochemical and Solid-State Letters 2007, 10 (10), B161-B165. (67) Gourba, E.; Ringuede, A.; Cassir, M.; Billard, A.; Päiväsaari, J.; Niinistö, J.; Putkonen, M.; Niinistö, L., Characterisation of Thin Films of Ceria-Based Electrolytes for Intermediatetemperature-Solid Oxide Fuel Cells (IT-SOFC). Ionics 2003, 9 (1-2), 15-20.

(68) Bernay, C.; Ringuedé, A.; Colomban, P.; Lincot, D.; Cassir, M., Yttria-Doped Zirconia Thin Films Deposited by Atomic Layer Deposition ALD: a Structural, Morphological and Electrical Characterisation. Journal of Physics and Chemistry of Solids 2003, 64 (9-10), 17611770. 